\title{
DIE BREUK TUSSEN DIE CHRISTENDOM EN DIE JODEDOM IN DIE EERSTE TWEE EEUE nC
}

\author{
H F STANDER
}

\begin{abstract}
The break between Christianity and Judaism in the first two centuries AD

It is argued that a radical break between Christianity and Judaism originated in the second half of the first century $A D$. This sharp separation persisted in the subsequent centuries. In this article the relationship between the early Christians and the Jews in the first two centuries is studied. The issue is approached from three different angles, namely (a) How did the pagans (the Greeks and the Romans) see the Christians? (b) How did the Jews behave towards the Christians? (c) How did the Christians behave towards the Jews? All statements are based on quotations from primary texts outside the New Testament.
\end{abstract}

Daar heers 'n algemene opvatting dat die vroeg-Christelike kerk eers diep in die tweede eeu nC finaal met die Jodedom gebreek het. Hierdie gedagte lê ook ten grondslag van verskeie sekondêre werke oor die eerste kerk se teologie en liturgie. Die doel van hierdie studie is om aan te toon dat daar baie vroeg reeds ' $n$ radikale breuk tussen die Christendom en die Jodedom ontstaan het. Hierdie diep skeuring tussen die kerk en die sinagoge was vanaf die tweede helfte van die eerste eeu regdeur die tweede eeu (en die daaropvolgende eeue) aan die orde van die dag. Dit blyk derhalwe dat die Joodse karakter van die vroeë kerk dikwels deur moderne werke oorspeel word. Voorts word uitsprake oor die onderhawige saak gewoonlik uitsluitlik op die Nuwe Testament geskoei. In hierdie studie egter, sal die verhouding tussen die eerste Christene en die Jode bespreek word op grond van buite Nuwe-Testamentiese geskrifte, sowel Christelik as heidens.

Vorster" sê: "It is generally accepted that primitive Christianity was first a Jewish sect until it became largely Gentile under the influence of Hellenism". Die belangrike vraag wat in hierdie artikel aangespreek word, is: "Hoe lank het die Christendom 'n Joodse sekte gebly? Slegs tot die val van Jerusalem, of dalk tot die rebellie van Bar-Cochba, of selfs tot nog later?" Daar sal deurentyd gepoog word om hierdie saak toe te lig met aanhalings uit primêre tekste.

Natuurlik sou dit dwaas wees om te ontken dat die eerste kerk in 'n Joodse wieg gebore is, MAAR die vroeë kerk het vanweë sy snelle uitbreiding al gou ontwikkel tot 'n potpourri van godsdienstige elemente. Van oral oor het daar invloede op die Christendom ingewerk, waarvan die 
Joodse element maar een was. Van baie vroeg af het die eerste Christene hulle egter gedistansieer van hulle Joodse broers. Daar moet dus gewaak word daarteen dat ons vandag te veel fokus op die Joodse element in die vroeg-Christelike kerk.

Die bespreking oor die verhouding van die Christendom tot die Jodedom in die eerste twee eeue word vanuit drie invalshoeke benader, te wete:

(a) Hoe die heidene (Romeine en Grieke) die Christene gesien het.

(b) Hoe die Jode teenoor die Christene opgetree het.

(c) Hoe die Christene teenoor die Jode opgetree het.

(a) HOE DIE HEIDENE (ROMEINE EN GRIEKE) DIE CHRISTENE GESIEN HET

Dit is interessant dat die heidene, volgens hul eie getuienis wat vir ons bewaar gebly het, nooit die Christene as 'n Joodse sekte gesien het nie. Daar kan redeneer word dat die heidene nie noodwendig reg was nie, maar die feit bly staan dat die Christene nie as 'n Joodse sekte beskou is nie. Hoe iets gesien word, is nou wel nie die somtotaal van wat dit werklik is nie, maar dit gee tog 'n aspek daanvan weer.

Maar voordat daar gekyk word na hoe die heidene wél die Christene gesien het, moet ons eers enkele opmerkings maak oor hoe die Jode gesien is. In die oë van die heidene was die volgende kenmerke tiperend van die Jode, naamlik (i) die besnydenis, (ii) die hou van die Sabbat en (iii) die vermyding van sekere kossoorte, oftewel die vas. Sommige van hierdie elemente mag wel by ander kulture ook voorgekom het, maar dit was nogtans gesien as kenmerkend van die Jode. Interessant genoeg was dit juis ook hierdie tipiese kenmerke van die Jodedom wat hulle dikwels die onderwerp van bespotting by ander volkere gemaak het. Nie een van hierdie voorskrifte is egter deur die Christene nagekom nie. Trouens, ook die vroeë Christene het die spot gedryf met hierdie kenmerke van die Jode. ${ }^{2)}$ Alhoewel die heidene neergesien het op die Jode, het laasgenoemde wel respek afgedwing by die heidene omdat hulle 'n ou godsdiens gehad het. Vir die heidene was die nakoming van die tradisies van die voorvaders baie belangrik. ${ }^{3)}$ Dit was juis die nuutheid van die Christendom en die feit dat hulle so laat op die toneel verskyn het wat dikwels as aanklag teen die vroeë Christene gebruik is.

Kom ons egter by die Christendom, is dit duidelik dat die heidene hulle nie as ' $n$ Joodse sekte gesien het nie, maar as 'n superstitio (kultus) en as 
'n filosofiese skool. Tacitus, byvoorbeeld, skryf kort na $110 \mathrm{nC}$ soos volg:

Christus, die skepper van die naam, is ter dood veroordeel deur die prokurator Pontius Pilatus tydens die bewind van Tiberius. Die verderflike kultus (superstitio) is vir 'n tydjie onderdruk, maar dit het weer uitgebreek, nie alleen in Judea, die plek van oorsprong van die siekte nie, maar ook in die hoofstad self, waar alle afgryslike of skandelike dinge van oral oor toestroom en floreer (Ann. 15:44:2-4).

Maar ook Plinius, die goewerneur van Bithinië, skryt in die herfs van 112 nC'n brief aan die keiser Trajanus rakende die Christene en sê onder andere: "Ek het gereken dat dit des te meer nodig was om deur middel van foltering die waarheid te trek uit twee slavinne wat diakonesse genoem is. Ek het niks anders gevind as 'n slegte en onbeteuelde kultus (superstitio) nie" (Ep. 96).

'n Entjie verder sê hy weer: "Nie slegs die stede nie, maar ook die dorpe en plattelandse gebiede is besmet met hierdie kultus (superstitio)" (Ep. 96).

Dit is veral belangrik om daarop te let dat Plinius sy gevolgtrekkings maak nadat hy 'n persoonlike onderhoud met twee Christene gehad het. Hy het dus eerstehandse kennis van die Christendom gehad.

Ook Suetonius, wat waarskynlik saam met Plinius in die jaar $111 \mathrm{nC}$ die provinsie Bithinië besoek het, skryf soos volg: "Die Christene, 'n groep mense wat behoort tot ' $n$ ' nuwe en slegte kultus (superstitio), is gestraf" (Nero 16).

Voorts het ook die heidense retorikus en filosoof Lucianus van Samosata (120-180) die Christendom as 'n kultus bestempel: "(Christus) is in Palestina gekruisig omdat hy hierdie nuwe kultus (teletén) in die wêreld ingebring het" (Peregrinus 11).

Maar wat was 'n superstitio? Hierdie term is gewoonlik gebruik vir 'n godsdiens wat vreemd en ongewoon was in Rome en wat gepaard gegaan het met ongewone en ekstatiese gedrag. Voorts is daar geglo dat so 'n godsdiens aan mense verkeerde opvattinge gee rakende die gode en hulle derhalwe goddeloos maak. Trouens, Plutarchus self vertel ons dat superstitio baie na aan goddeloosheid grens. ${ }^{4}$ Die karikatuur wat van die vroeë Christene geskep is en hulle "oneerbiedigheid", "ateïsme" en "immoraliteit" het gemaak dat hulle goed ingepas het by dit wat met superstitio bedoel is.

Galenos (129-199) redeneer dat die Christene soveel morele dissipline aan die dag lê dat hulle byna op dieselfde vlak verkeer as diegene wat "filosofies" leef. Hulle was wel in sekere opsigte, volgens hom, laer as die filosofiese skole maar tog bewonderenswaardig vir hul morele erns. 
Hy sê: "In hulle (Christene) veragting van die dood ... hulle selfbeheersing ten opsigte van saamwoon ... hulle selfdissipline en selfbeheersing ten opsigte van voedsel en drank, en in hulle ywerige najaag van geregtigheid, het hulle 'n vlak bereik wat nie ondergeskik is aan hulle wat waarlik filosofies leef nie" (De pulsum differentiis 3.3; 2.4). ${ }^{\text {) }}$

Geen wonder dan dat die Christen-apologete hierdie idee van die Christendom as 'n "filosofie" opgeneem het nie. So byvoorbeeld skilder Justinus sy bekering tot die Christendom as 'n bekering tot ' $n$ "filosofiese skool". Justinus, gebore in $100 \mathrm{nC}$, vertel dat 'n ou man met hom oor Christus gepraat het en sê:

En toe hy hierdie en nog baie ander dinge gesê het, waarvoor daar nie nou tyd is om dit tevertel nie, het hy weggegaan nadat hy my beveel het om dit na te volg, en ek het hom nie weer gesien nie. Dadelik is 'n vuur in my siel aangesteek, en 'n liefde vir die profete en daardie manne wat vriende van Christus is, het my beetgepak. Terwyl ek sy woorde by myself beredeneer het, het ek hierdie filosofie alleen veilig en nuttig gevind. Op grond hiervan is ek dan 'n filosoof (Dial. 8:1,2).

Dit is interessant dat Christus ook in die kuns van die eerste eeue $\mathrm{nC}$ dikwels as 'n filosoof met 'n boekrol in sy hand uitgebeeld is.

Die eerste heiden wat wel klem gelê het op die band tussen die Jodedom en Christendom was die filosoof Celsus, maar dan wys hy in elk geval op die Christene se atwyking van Judaïsme. Hy het'n grondige kennis van sowel Judaïsme as die Christendom gehad. In sy boek, Ware Woord, wat in $178 \mathrm{nC}$ geskryf is, stel Celsus onder andere 'n Jood aan die woord wat die volgende sê: "Hoe is dit dat die oorsprong van julle geloof in ons godsdiens (Jodedom) geleë is, maar wanneer julle gevorder het, minag julle dit, alhoewel julle nie 'n ander basis as ons wet vir julle dogma het nie?" (Origenes C.C. 2:4).

Ook die heiden Diognetus (indien dit nie 'n fiktiewe persoon was nie), doen duidelik navraag "waarom die Christene nie op dieselfde wyse godsdiens beoefen as die Jode nie" (Diog. 3).

Dus, om hierdie afdeling af te sluit, moet ons sê dat dit blyk of die Christene aan die begin van die tweede eeu $\mathrm{nC}$ alreeds in so 'n mate gebreek het met die Jode dat die heidene hulle glad nie gesien het as net nog 'n Joodse sekte nie. Inteendeel, vir die heidene was die Christendom 'n superstitio en 'n filosofiese beweging. ${ }^{6)}$

\section{(b) HOE DIE JODE TEENOOR DIE CHRISTENE OPGETREE HET}

Allereers moet mens onthou dat die skeiding tussen die Jodedom en die 
Christendom, en veral die invloed van eersgenoemde op laasgenoemde, ook deur sosiale en politieke faktore bepaal is. Daar het 'n sterk kerk in Antiochië en Klein-Asië ontstaan en verder het die kerk in Rome in toenemende mate 'n vername rol begin speel vanweë die politiese belangrikheid van laasgenoemde stad. Dit het ongetwyfeld die rol en invloedsfeer van die Palestynse Judaïsme op die Christendom erg beperk. Na die val van Jerusalem voor Titus in $70 \mathrm{nC}$ het die opvolging van biskoppe in Jerusalem alle belangrikheid verloor.

Maar die Jode het ook daadwerklike stappe geneem om verdere skeiding tussen die Jodedom en die Christendom te bewerkstellig. Ongelukkig is daar min inligting hieroor in die Joodse literatuur wat voor $200 \mathrm{nC}$ gedateer word. Kennis oor die Jode se optrede teenoor die Christene kom dus hoofsaaklik uit geskrifte van Christene. Dit noop ons om versigtig om te gaan met die stof en bedag te wees op bevooroordeeldheid. Die kerkvaders vertel ons egter dat die Jode mense rondgestuur het om die Christene te belaster en dat hulle selfs per briewe mense teen die Christene gewaarsku het. Justinus vertel ons op verskeie plekke daarvan. Een van hierdie gedeeltes lui soos volg:

Want ander nasies het nie in dieselfde mate as julle hierdie onreg aan ons en aan Christus gedoen nie. Julle is die oorsaak van 'n bose vooroordeel teen die Regverdige en teen ons wat aan Hom behoort... In daardie tyd het julle uitverkore manne uitgekies en uitgestuur uit Jerusalem oor die hele land om te vertel dat die goddelose kettery van die Christene ontspring het en julle het uitgewei oor hierdie dinge wat hulle, wat nievir ons ken nie, oor ons vertel (Dial. 17).

Soos die bekende historikus Frend ${ }^{7}$ ) terer jê, lyk dit of hierdie gebruik ver teruggaan tot selfs voor die val van Jerusalem en dat dit daarna voortgeduur het tot in die tyd van Justinus. Trouens, die Jode het ook ná die tyd van Justinus nog steeds hiermee voortgegaan tot so 'n mate dat selfs Origenes ons met min of meer dieselfde woorde hiervan vertel. ${ }^{8)}$ Dit is nogal interessant dat Eusebius hierdie praktyk bevestig wanneer hy soos volg skryf:

Ons het in hierdie ou geskrifte gevind dat die priesters en die oudstes van die Joodse nasie wat in Jerusalem gewoon het, briewe opgestel het en dat hulle dit gestuur het na alle nasies en dat hulle valse gerugte versprei het oor die leer van Christus oral oor onder die Jode, naamlik dat dit'n nuwe kettery was wat vyandiggesind teenoor God was. Ook het hulle per brief opdrag gegee om nie Christene te aanvaar nie ( $/ \mathrm{n}$ Is. 18.1). 
Verder het die Jode in ongeveer $85-95 \mathrm{nC}$ 'n bede bygevoeg tot die Shemonah Esre, naamlik die Birkat ha-Minim. Dit was 'n vloek teen die ketters, insluitende die Christene. Vanaf hierdie tyd was dit haas onmoontlik vir enige Joodse Christen om die sinagoge te besoek as hy nie 'n vloek teen homself wou uitspreek nie. Interessant genoeg lees ons ook by die kerkvaders van hierdie gebruik soos wanneer Justinus aan die Jood Trypho sê:

En hierdie dinge het billikerwys en regverdiglik met julle gebeur, want julle het die Regverdige doodgemaak, en sy profete voor Hom, en nou verwerp julle diegene wat op Hom hoop asook die Een wat Hom gestuur het, naamlik God, die Almagtige, Skepper van alles, en in julle sinagoges vloek julle dié wat in Christus glo. Want julle het nie die mag om die hande op ons te lê nie vanweë hulle wat tans in die magsposisie is. Maar so dikwels as wat julle kon, het julle dit gedoen (Dial. 16).

Ook op 'n ander plek sê Justinus:

Ek is van mening dat hulle wat uit die nageslag van Abraham is, maar lewe volgens die wet, en nie voor hulle dood glo in hierdie Christus nie, dat hulle insgelyks nie gered sal word nie, en veral hulle wat in die sinagoges hierdie einste Christus vervloek het en nog steeds vervloek (Dial. 47).

Later sê Justinus weer: "Want julle vervloek in julle sinagoges almal wat deur Hom Christene genoem word" (Dial. 96).

Daarbenewens het die Jode ook 'n verbod geplaas op die lees van ketterse boeke (sifre minim). Dit was moontlik juis gemik op die gebruik van die Skrif deur Joodse Christene. Dit moes beslis vir die Christene ondraaglik geword het om hul byeenkomste in sinagoges te hou. Geen wonder dat ons nêrens in enige Patristiese geskrif getuienis vind dat Christene nog die sinagoges besoek het nie. Inteendeel, ons lees juis dat Christene uitsluitlik in huise bymekaar gekom het. Toe Justinus byvoorbeeld voor die regsbank verskyn het vanweë sy geloof, het Rusticus, die prokurator, hom gevra: "Vertel ons waar julle bymekaarkom of op watter plek jy jou volgelinge versamel". Justinus antwoord dan: "Ek bly bo 'n sekere Martinus van die Timiotiniese badhuis, en oor al die tyd heen ken ek geen ander bymekaarkomplek as syne nie, en ek bly nou die tweede keer in die stad Rome" (Hnd. Just. 3). Verder is die Christene juis as een of ander geheime organisasie beskou omdat hulle nie sigbare plekke van byeenkoms gehad het nie. Dit word bywoorbeeld uitdruklik gesê deur die heidense filosoof Celsus.9) Kortom, die sinagoges kon van vroeg af nie meer as bymekaarkomplek gebruik word nie.

'n Mens moet aanneem dat daar wel moontlik groepe Christene was 
wat hulle ook aan die Joodse wet gehou het. Justinus vertel ons juis van sulke Christene en sê hy glo dat sulke mense tog nog gered sal word. Dit lyk egter of hierdie groepe eerder die uitsondering as die reël was. Justinus sê soos volg:

Maar, o Trypho, as sommiges van jou geslag (Jode), wat sê dat hulle in hierdie Christus glo, vir die heidene wat in hierdie Christus glo verplig om in alles te leef volgens die Wet wat deur Moses gegee is, of Verkies om nie te innig met hulle om te gaan nie, keur ek dit insgelyks nie goed nie. Maar ek reken dat diegene wat oorreed is deur hulle tot' $n$ wettiese bedeling tesame met die nakoming van hul belydenis van God in Christus, dat hulle ook moontlik gered sal word (Dial. 47).

Wat die Jode se houding teenoor die Christene betref, lees ons dat "Christene deur die Jode bestry is soos vreemdelinge". ${ }^{10)}$ Ons lees dat toe Polykarpos gemartel is, die Jode alte graag daarmee gehelp het: "En die skare het dadelik met hout en bosse bymekaargekom uit die werksplekke en badhuise en, soos gewoonlik, het veral die Jode ywerig meegehelp hiertoe" (Mart. Pol. 13).

Let op dat die outeur sê dat dit die "gewoonte" was van die Jode om so hulpvaardig te wees met die marteling van Christene. Dit dui derhalwe op 'n gevestigde gebruik.

Om hierdie afdeling af te sluit kan mens nie anders nie as om te sê dat daar van baie vroeg reeds, vanaf die tweede helfte van die eerste eeu, 'n daadwerklike poging by die Jode was om hulle van die Christene te distansieer. Die Jode was beslis ook suksesvol in hulle poging om die boodskap uit te dra dat die Christene nie sommer net nog 'n Joodse sekte was nie, want van baie vroeg af is die Christene swaar vervolg. Die Jode het dus seker gemaak dat die Romeinse verdraagsaamheid teenoor die Joodse godsdiens nie ook beskerming aan die Christene verleen het nie. Dit is wel so dat ook die Jode soms swaar vervolg is, maar dan was dit vanweë politieke opstande. Die vervolging was nooit primêr teen hulle godsdiens gemik nie, soos in die geval van die Christene nie.

Op die ou einde moet mens sê dat die breuk tussen die Christendom en die Jodedom van vroeg af ook deur die Jode se houding en optrede aangehelp is. Die feit dat die Jode van die Christene verwag het om hulle by te staan in die Bar-Cochba-rebellie tussen 132-135 nC, moet nie vertolk word dat hulle in hierdie stadium nog geglo het dat die Christene deel van hulle was nie. Die Jode het ook op die Christene 'n beroep om hulp gedoen omdat hulle gereken het dat Jerusalem ook vir die Christene religieuse betekenis gehad het en verder het hulle die beroep om politiese redes gedoen. Mor ${ }^{11}$ wys byvoorbeeld daarop dat, volgens die getuienis van Dio Cassius, daar ook nie-Jode aan die rebellie deelgeneem het. 
Volgens Mor het diesulkes veral uit die laer klasse in die Hellenistiese stede gekom. Hulle het gehoop dat hulle deur die omverwerping van die Romeine die aristokratiese klas, wat hoofsaaklik bestaan het uit die Romeine, kon verwyder en sodoende hul eie posisie kon verbeter.

Kortom, die Jode het van vroeg af daartoe bygedra dat die skeuring tussen Jood en Christen algaande verdiep het. ${ }^{12)}$

\section{(c) HOE DIE CHRISTENE TEENOOR DIE JODE OPGETREE HET}

Die Christene het hulself gesien as 'n voortsetting van die Ou-Testamentiese volk van God. Die groot probleem was egter dat die Jodedom nie opgehou het om te bestaan nie. Die Christene kon nie begryp hoe die Jode nie hulle Messias kon aanvaar nie, veral nadat God sy afkeur van Judaïsme so duidelik gewys het met die vernietiging van die tempel in Jerusalem in die jaar $70 \mathrm{nC}$. Verder, soos dit so dikwels gebeur, is die vyandskap tussen bloedverwante veel intenser as die vyandskap tussen vreemdelinge. Net so was die gevoel tussen die Christene en die Jode na die val van Jerusalem baie vyandig en dit het die skeuring verdiep.

Maar kom ons kyk na wat die antieke Christelike teoloë self gesê het oor hulle verhouding met die Jode. Ons het hier egter wel die probleem dat die datering van sommige van die vroeë patristiese geskrifte debatteerbaar is. Dit val egter buite die doelstelling van hierdie artikel om in te gaan op die argumente vir die datering van elke werk wat hier aangehaal word, en daarom sal die nuutste en mees gesaghebbende bronne bloot as gegewe aanvaar word. Immers, die outeurs van laasgenoemde sekondêre bronne was in elk geval nie subjektief betrokke by die onderhawige tema toe hulle onderstaande patristiese werke gedateer het nie.

Laat ons begin met die Apostoliese Vaders waarin ons reeds lees van 'n skeuring tussen die Judaïstiese en die Christelike gemeenskappe en van'n wedersydse verwerping van mekaar.

\section{(i) Die Barnabasbrief}

Die Oxford Dictionary of the Christian Church ${ }^{13)}$ dateer hierdie brief tussen 70 en $100 \mathrm{nC}$. Redelik onlangs (in 1983) het Gunther ${ }^{14}$ ) stewige argumente aangevoer waarom hierdie werk voor $80 \mathrm{nC}$ gedateer moet word. Dit lyk dus of dit kort na die verwoesting van die tempel in Jerusalem geskryt is. Reeds in hierdie vroeë stadium bemerk ons'n duidelike breuk met die Jodedom. Om die waarheid te sê, 'n sterk anti-Judaïstiese houding kan in feitlik elk van die hoofstukke bespeur word. Barnabas sê dat God die Joodse wyse van aanbidding opgehef het. Hy gebruik ook die verhale 
van Isak se twee seuns (Esau en Jakob) asook dié van die twee seuns van Josef (Manasse en Efraim) om te bewys dat die Joodse wyse van aanbidding verval het. Volgens hom dien die twee broers telkens as tipes van die Jode en die Christene. In albei gevalle moes die ouere die jongere gedien het. Daarmee bewys hy dat die Jode hulle voorregte verbeur het. Hy vertel ook verder dat daar afstand gedoen is van die Joodse gebruik om die sewende dag as die Sabbatdag te gedenk. Die Christene vier eerder die agste dag, naamlik die Sondag, aangesien die Here ook op hierdie dag opgestaan het uit die dode.

Verder argumenteer die outeur dat die Jode God se bevele heeltemal verkeerd verstaan het deur dit letterlik te interpreteer. Hy sê slegs die Christene se interpretasie daarvan rym met God se wil (hfst 10). Hy beskou ook nie meer die Jode as 'n uitverkore nasie nie, maar eerder as 'n volk wat deur God verwerp is (hfst 4:14). Uiteindelik kan mens nie anders as om die hele Barnabasbrief as 'n anti-Judaïstiese traktaat te bestempel nie. Die feit dat hierdie werk kanonieke gesag gehad het, is veelseggend. Die inhoud van hierdie werk moes dus wye erkenning onder die eerste Christene geniet het.

Moontlik kan mens wel nog Joodse invloede bespeur in die Barnabasbrief, soos in die metode van interpretasie. Frend ${ }^{15}$ ) byvoorbeeld, is van mening dat hierdie werk aangebied is soos 'n rabbi dit sou doen en dat hoofstukke 1-17 'n haggadah vorm terwyl 18-20 weer 'n halakah vorm. Ons moet egter duidelik tussen vorm en inhoud onderskei. Dit mag wel wees dat, vanweë die Joodse wieg waarin die Christendom gebore is, sekere Joodse invloede deurgewerk het. Alhoewel enkele vorms moontlik behoue gebly het, is dit nogtans onteenseglik so dat Christene van baie vroeg af nuwe inhoud daaraan gegee het.

\section{(ii) Die Didaché}

Kom ons by die Didaché, het ons onmiddellik weer'n dateringsprobleem. Voorstelle wat deur geleerdes gemaak word, wissel vanaf $40 \mathrm{nC}$ tot selfs in die vierde eeu $\mathrm{nC}$. Die bekende kerkhistorikus Chadwick ${ }^{16)}$ plaas dit tussen 70 en $110 \mathrm{nC}$. Ook Klijn ${ }^{17)}$ plaas die Didaché aan die begin van die tweede eeu en voer ' $n$ hele aantal argumente aan waarom dit nie later geplaas kan word nie.

In die Didaché maak die outeur hom uitdruklik los van die Joodse vastye. Die Jode het op Maandae en Donderdae gevas, en juis daarom bepaal die Didaché dat die Christene dan eerder op Woensdae en Vrydae moet vas (hfst 8). In hierdie werk word die Jode ook "geveinsdes" genoem (hfst 8). 


\section{(iii) Clemens Romanus}

Oor die Eerste Brief van Clemens is daar redelike eenstemmigheid by die meeste geleerdes dat dit in die eerste eeu geskryf moes gewees het. Dit lyk nogal of die jaar $96 \mathrm{nC}$ groot byval vind. Clemens het in 'n baie groot mate die Ou Testament gebruik in sy geskrif. Mens kan amper sê dat by Clemens die Ou Testament geheel en al deur die Christelike kerk geannekseer is. Hier is nogal 'n belangrike onderskeid wat gemaak moet word. Die vroeë Christene het dikwels swaar geleun op die Ou Testament, maar nie noodwerrdig op die Judaïsme nie. Mens moet in elk geval onthou dat die Nuwe-Testamentiese kanon nog nie gevestig was nie.

Die Tweede Brief van Clemens, wat beslis nie dieselfde outeur as die eerste brief het nie, word gewoonlik êrens tussen 120 en 170 nC gedateer. Eintlik is dit geen brief nie, maar eerder 'n preek. Die outeur sê eksplisiet in hoofstuk 19 dat hy hierdie geskrif hardop lees en dit lyk asof dit binne 'n liturgiese opset geskied. In hoofstuk 2:3 is daar een gedeelte waarin dit lyk of die outeur 'n onderskeid tref tussen die Judaïsme en die Christendom en dat hy glo dat laasgenoemde meer verhewe is: "En toe Hy gesê het 'die kinders van die verlatene is baie meer as van haar wat 'n man het', het hy bedoel dat ons volk wat gelyk het asof hulle verlate is van 'n God, noudat ons geglo het, meer geword het as hulle wat lyk of hulle 'n God het".

\section{(iv) Briewe van Ignatius}

Ignatius was 'n biskop van Antiochië in Sirië. Hy het in $108 \mathrm{nC}$ as martelaar in Rome gesterf toe hy vir wilde diere gegooi is. Op pad na sy teregstelling toe in Rome het hy verskeie briewe geskryf. In hierdie briewe, wat derhalwe voor 108 geskryf moes gewees het, maak Ignatius baie skerp opmerkings oor die Judaïsme. Enkele aanhalings uit slegs twee van hierdie briewe sal reeds genoegsame bewys hiervan lewer.

Moenie mislei word deur vreemde leringe of ou fabels wat nutteloos is nie, want as ons nog steeds volgens die Judaïsme leef, dan erken ons dat ons nie genade ontvang het nie (Magn. 8).

en

Dit is verregaande om van Jesus Christus te praat maar soos 'n Jood te leef, want die Christendom baseer nie sy geloof op die Jodedom nie, maar die Jodedom op die Christendom; in laasgenoemde is mense van elke taal deur geloof in God versamel (Magn. 10). 
As iemand die Judaïsme aan julle uitlê, moenie na hom luister nie, want dit is beter om die Christendom van ' $n$ besnedene te verneem as Joodse opvattinge van ' $n$ onbesnedene. As nie een van hulle oor Jesus Christus praat nie, dan is hulle vir my grafte en grafstene, waarop slegs die name van mense geskryt is. Ontulug dus die bose liste en strikke van die owerste van hierdie wêreld, sodat julle nie verstik in sy plan en swak word in die geloof nie (Phil. 6).

Dit is dus onteenseglik dat daar teen die jaar $108 \mathrm{nC}$ al 'n diepe skeuring tussen die Jodedom en die Christendom was, soos dit blyk uit die briewe van Ignatius.

\section{(v) Diognetusbrief}

Die Diognetusbrief word gewoonlik tussen 125 en $200 \mathrm{nC}$ gedateer. ${ }^{18)}$ Die outeur neem 'n radikale houding in teenoor die Judaïsme. Hy wil selfs nie eens toegee dat die Joodse gebruike wel deur God ingestel is of dat dit tipologies heengewys het na Christus se koms nie. Sy standpunt is eintlik anti Nuwe-Testamenties as mens kyk na sy ongekwalifiseerde verdoeming van die Judaïsme as ' $n$ absurditeit. Hy skryf:

Maar, inderdaad, ek dink nie dat jy nodig het om van my te leer dat die Jode se angsvalligheid in verband met voedselsoorte, en hulle bygeloof in verband met die Sabbatte, en hulle gespog oor die besnydenis en hulle huigelary in verband met die vas en die fees van die nuwe maan lagwekkend is en geen argument werd is nie. Want hoe kan dit nie onwettig wees om sommige van die dinge wat deur God geskape is vir die gebruik van mense te aanvaar as goed geskape, maar ander dinge te weier asof dit nutteloos en oorbodig geskape is nie? En hoe is dit nie goddeloos om vals lik van God te sê dat Hy verbied om iets goed te doen op 'n Sabbatdag nie? Hoe is dit nie waardig van bespotting om te roem op die skending van die vlees as bewys van uitverkiesing asof hulle juis daarom spesiaal deur God bemin word nie? Maar hulle inagneming van maande en dae deur die sterre en maan te betrag, en dat hulle die bestuur van God en die wisseling van die tye inrig tot hulle eie voorkeure - terwyl hulle sommige omskep tot feeste en andere tot tye van rou - wie sou reken dat dit 'n voorbeeld is van godsdienstigheid en nie veel eerder van dwaasheid nie? Wel, ek dink dat jy voldoende geleer het dat die Christene hulle heel tereg weerhou van die algemene gekheid, bedrog, puntenerigheid en hoogmoed van die Jode (Diog. 4).

\section{(vi) Justinus}

Justinus het ten tye van die Bar-Cochba-rebellie 'n traktaat teen die Jode 
geskryf, getiteld Dialoog met die Jood Trypho. Hierdie hele geskrif, wat omtrent net so lank is as al vier evangelies saam, wemel van anti-Joodse materiaal, en derhalwe is dit prakties onmoontlik om dit in die bestek van hierdie artikel te behandel. Williamson ${ }^{19}$ gee egter vir ons 'n nuttige oorsig van die temas wat Justinus aansny.Die belangrikste hiervan is die volgende: Die nuwe wet hef die ou wet op; die Jode verwerp die nuwe wet vanweë hulle blindheid; mens kan nie in die regte verhouding met God geplaas word deur die nakoming van die Joodse insettinge nie; Die Jode ly omdat hulle Christus doodgemaak het; die insettinge van die ou verbond is aan die Jode gegee vanweë al hul oortredinge en die hardheid van hulle hart; Die Joodse uitleg van die Ou Testament is waardeloos; Die Jode is verwerp terwyl die heidene uitverkies is.

\section{(vii) Melito}

Melito was biskop van Sardis en in ongeveer $177 \mathrm{nC}$ het hy 'n preek vir Paasfees geskryf, getiteld PeriPascha. Hierin beskuldig Melito vir die Jode in skerp taal dat hulle Christus vermoor het:

Dit is Hy wat vermoor is;

En waar is Hy vermoor?

In die middel van Jerusalem!

Deur wie? Deur Israel!

Waarom? Omdat Hy hulle lammes genees het

en hul melaatses gereinig het en

hulle blindes na die lig gebring het

en hulle dooies opgewek het,

daarom het Hy gesterf (Peri Pascha 72).

en

"Ek" sê Israel, "het die Here doodgemaak"

"Waarom"? "Omdat Hy moes sterwe"

"Jy maak 'n fout, O Israel, wanneer jy dit dink

oor jou slagting van die Here.

Hy moes ly, maar nie deur jou nie;

Hy moes onteer word, maar nie deur jou nie;

Hy moes veroordeel word, maar nie deur jou nie;

Hy moes gehang word, maar nie deur jou

en jou regterhand nie" (Peri Pascha 74-5).

en

En jy was verheug, 
terwyl Hy van honger sterwende was;

jy het wyn gedrink en brood geëet,

maar Hy asyn en gal;

jou gesig was glansend,

maar Hy was terneergedruk;

jy was opgewek,

maar Hy verdruk;...(Peri Pascha 80$)$.

en

Luister al die families van die nasies en kyk:

'n vreemde moord het in die middel van Jerusalem plaasgevind, die stad van die wet,

in die stad van die Hebreërs,

in die stad van die profete,

in die stad wat as regverdig beskou word.

En wie is vermoor? Wie is die moordenaar?

Ek is skaam om te sé maar genoodsaak om te vertel.

Want as die moord in die nag plaasgevind het,

of as $\mathrm{Hy}$ vermoor is in die woestyn,

was dit maklik om te swyg.

Maar nou in die middel van die straat en in die middel van die stad

in die middel van die dag terwyl almal kyk

het 'n onregverdige moord van 'n regverdige man plaasgevind ...

God is vermoor;

Die Koning van Israel is doodgemaak deur' $n$ regterhand van 'n Israeliet (Peri

Pascha 94, 96).

Die vroeë Christene het van die begin af alle blaam vir die dood van Jesus vierkantig op die skouers van die Jode geplaas terwyl hulle Pilatus heeltemal verontskuldig het. Om die waarheid te sê, in die Koptiese Kerk word die naam van sowel Pilatus as sy vrou vandag nog tussen die name van die ander heiliges gevind. Hoor wat sê Melito:

Maar jy (Israel) het die teenoorgestelde lot teen jou Here gewerp;

Hy vir wie die heidene aanbid het

en die onbesnedenes bewonder het

en die vreemdelinge verheerlik het,

oor wie ook Pilatus sy hande gewas het,

jy het Hom doodgemaak op die groot feesdag (Peri Pascha 92).

Tertullianus sê selfs dat Pilatus 'n Christen was (Apol. 21). Aan die ander kant is dit nogal interessant om daarop te let dat die Jode self presies die teenoorgestelde van Pilatus sê. Philo, byvoorbeeld, beskryf Pilatus as "gevoelloos en genadeloos" (Legatio ad Gaium 301). 
Irenaeus het in ongeveer 178 biskop van Lyons geword. Een van sy belangrikste werke is die Adversus Haereses. In hierdie werk val hy ook die Gnostisisme aan. In die Gnostiek is daar onder andere 'n onderskeid gemaak tussen die God van die Hebreeuse Bybel en die Almagtige God. As mens in ag neem dat Irenaeus juis poog om in hierdie werk te veg vir die behoud van die Ou Testament, dan word dit des te meer eienaardig dat ook Irenaeus fel uitvaar teen die Jode. Irenaeus sê onder andere dat dit die Jode se verdiende loon was dat Jerusalem vernietig is (Adv. Haer. 4:4).

Irenaeus gaan selfs so ver as om 'n parallel te trek tussen die Jode en Kain, die eerste moordenaar:

Want aan die begin het God die offergawes van Abel aangeneem omdat hy met eenvoud en met opregtheid geoffer het. Hy het egter nie die offer van Kain aangeneem nie omdat sy hart verdeeld was deur jaloesie en boosheid jeens sy broer, soos God gesê het toe Hy sy verborge (gedagtes) berispe het: "Alhoewel jy reg offer, het jy nie nogtans gesondig as jy nie reg verdeel nie?" Dit is nie offers wat God gunstig stem nie ... Alhoewel dit lyk of hulle [Jode] reg offer wat die uiterlike betref, hethulle nes Kain jaloesie in hulle hart gehad. Daarom het hulle die Regverdige vermoor, terwyl hulle die advies van die Logos ignoreer, net soos Kain (Adv. Haer.4:18).

Ook Irenaeus beroep hom op die verhaal van die twee broers Jakob en Esau wat tipologies verklaar word as die Jode en die Christene: "In Christus is elke seëning saamgevat en daarom het die latere volk die Vader se seëninge van die vroeëre volk weggeraap, net soos Jakob die seëning van Esau weggeraap het. Daarom is die een broer deur die ander broer gejag, soos die Kerk soortgelyke lyding verduur deur die Jode" (Adv. Haer. $4: 21)$.

\section{(ix) Tertullianus}

Aangesien daar reg aan die begin gesê is dat hierdie studie handel oor die verhouding tussen die Jode en die Christene in die eerste twee eeue nC kan daar afgesluit word met Tertullianus wat in ongeveer $200 \mathrm{nC}$ ' $n$ werk geskryt het met die titel Adversus Judaeos. Tertullianus begin sommer die traktaat met weer eens 'n tipologiese uitleg van die twee broers Esau en Jakob waardeur hy die ondergeskikte posisie van die Jode bewys. Ook Tertullianus gebruik die argument van die vemietiging van die tempel teen die Jode en verder beskuldig hy hulle van moord op Jesus.

Tot nou toe het ons gekyk na dit wat die Christene, Jode en heidene 
geskryf het oor die Christene/Jode. Mens sou egter ook vanuit nieliterêre hoeke kon kyk na die verhouding tussen die Jode en die Christene, maar dit lê buite die doelstelling van hierdie artikel. In hierdie verband kan mens net noem dat die kuns van die vroeë Christene, van reg van die begin af, as Laat-Klassiek bestempel moet word. Van Joodse invloed is daar weinig sprake. Mens sou hierop kon reageer deur te sê dat die Jode nie hulself in kuns uitgedruk het nie, vanweë die oënskynlike Ou-Testamentiese verbod op kuns. Tog sou hierdie verduideliking nie korrek wees nie aangesien die opgrawings te Dura-Europos toon dat daar wel muurskilderinge voorgekom het in die Joodse sinagoges. Veel eerder moet dit toegeskryt word aan die vroeë skeiding tussen die Jodedom en die Christendom wat die invloed van eersgenoemde op laasgenoemde aansienlik beperk het. Dus was die styl van die Christelike kuns deur en deur klassiek. Die eerste Christene het selfs heidense temas net so oorgeneem en dit bloot verander deur nuwe inhoud daaraan te gee. Mens kan dit byvoorbeeld duidelik sien in die feit dat feitlik alle Christelike simbole net so uit die heidense wêreld oorgeneem is. Ook Christus is uitgebeeld as 'n Romeinse god.

Wat die vroeë Christene se musiek betref, kan daar verwys word na Quasten se studie Music and Worship in Pagan and Christian Antiquity. ${ }^{20}$ In hierdie boek wys Quasten daarop dat die Christene baie vroeg reeds gebreek het met die uitvoerige musikale versiering van die liturgie wat so kenmerkend was van die $\mathrm{Ou}$-Testamentiese tradisie. Om die musiek van die vroeë Christene te verstaan moet mens deeglik vertroud wees met die musiek van die heidene.

Ten slotte: Mens sal moet aanneem dat die intensiteit van die breuk tussen die Jode en die Christene verskil het van een geografiese gebied tot ' $n$ ander. Dit is egter baie moeilik om bogenoemde uitsprake elke keer tot 'n spesifieke geografiese gebied te beperk aangesien die meeste van ons oudste geskrifte baie moeilik gelokaliseer kan word. Verder moet mens onthou dat daar natuurlik verskillende Joodse groeperinge bestaan het en ons mag nooit aan die Jodedom dink as 'n verenigde front nie.

Nogtans, wat die kerk en die sinagoge in die breë betref, blyk dit duidelik dat daar reeds met die aanbreek van die tweede eeu, lank voor die Bar-Cochba-rebellie, 'n diepgaande breuk was tussen die Jodedom en die Christendom en dat hierdie verbrokkelde verhouding aan die orde van die dag was regdeur die tweede eeu. Die implikasies hiervan is ingrypend. Ons sal meer rekening moet hou daarmee dat die vroeë kerk deur 'n potpourri van elemente beïnvloed is. Die Joodse element is slegs een hiervan en, soos ons gesien het, gewis nie die belangrikste element nie. Die Joodse karakter van die eerste kerk word ongetwyteld oorspeel in moder- 
ne sekondêre werke. Wanneer die liturgie bespreek word, word dit vanuit 'n Joodse oogpunt gedoen. Wanneer die doop of nagmaal bespreek word, word dit weer eens teen 'n Joodse agtergrond gedoen, ensovoorts. Dit is die stand van sake ondanks die feit dat die eerste kerk nie vir lank sy Joodse kinderskoene gedra het nie.

\section{NOTAS}

1. W S Vorster, "On Early Christian Communities and Theological Perspectives", Journal of Theology for Southern Africa, Nr 59 (1987), 27.

2. Kyk Diognetusbrief 4.

3. Vgl Porphyrius Ad Marcellam 18.

4. Plutarchus De Superstitione.

5. Uit Engels vertaal soos aangehaal deur R L Wilken, "The Christians as the Romans (and Greeks) saw them", EP Standers (ed), Jewish and Christian Self-Definition, London 1980, 108.

6. Vir meer inligting sien A V van Stekelenburg, "Lucifugax natio - The Pagan View of Early Christianity", Akroterion vol 28 (1983) 157-171; Wilken, aw, 100-125; R L Wilken, The Christians As The Romans Saw Them, New Haven 1984.

7. W H C Frend, Martyrdom and Persecution in the Early Church, Oxford 1965, 192.

8. Origenes Contra Celsum 6:27.

9. Origenes Contra Celsum 8:17-18.

10. Diognetusbrief 5.17.

11. M Mor, "The Bar-Kokhba Revolt and Non-Jewish Participants", Journal of Jewish Studies vol 36 (1985) 200-209.

12. Vgl ook J Alvarez, "Apostolic Writings and the Roots of Anti-Semitism", Studia Patristica vol 13 (1975) 69-76; B Z Bokser, "Justin Martyr and the Jews (I)" The Jewish Quarterly Review vol 64 (1973), 97-122; B Z Bokser, "Justin Martyr and the Jews (II)", The Jewish Quarterly Review vol 65(1974), 204-211; J L Daniel, "Anti-Semitismn the Hellenistic-Roman Period", Journal of Biblical Literature vol 98 (1979), 45-65; P J Donahue, "Jewish Christianity in the Letters of Ignatius of Antioch", Vigiliae Christianae vol 32 (1978), 81-93; D Flusser, "The Jewish-Christian Schism (Part I)" Immanuel vol 16 (1983), 32-49; D Flusser, "The Jewish-Christian Schism (Part II)" Immanuel vol 17 (1983/4), 30-42; ST Katz, "Issues in the Separation of Judaism and Christianity after 70 CE:A Reconsideration", Journal of Biblical Literature vol 103 (1984), 43-76; H Maccoby, "Christianity's Break with Judaism", Commentary vol 78(1984), 38-42; W E March, "Whence Anti-Semitism?", Theology Today vol 41 (1984/5), 275-279; K W Noakes, "Melito of Sardis and the Jews", Studia Patristica vol 13 (1975) 244-249; D Rokeah, "Anti-Judaism in Early Christianity", Immanuel vol 16 (1983), 50-64; G N Stanton, "Aspects of Early Christian-Jewish Polemic and Apologetic" New Testament Studies vol 31 (1985), 377-392.

13. F L Cross and E A Livingstone (eds), The Oxford Dictionary of the Christian Church, Oxford 1978, 134.

14. J J Gunther, "The Association of Mark and Barnabas with Egyptian Christianity (II)", The Evangelical Quarterly vol 55(1983), 25-29.

15. W H C Frend, The Rise of Christianity, London 1984, 122.

16. H Chadwick, The Early Church, England 1981, 47. 
17. A F J Klijn, Apostolische Vaders 1, Kampen 1981, 230.

18. Vgl W A Jurgens, The Faith of the Early Fathers, vol I, Collegeville 1970, 40.

19. C M Williamson, "The 'Adversus Judaeos' Tradition in Christian Theology", Encounter vol 39 (1978), 273-296.

20. J Quasten, Music and Worship in Pagan and Christian Antiquity (Trans by B Ramsey), Washington 1983. 